Ingalls, T. H., and Prindle, R. A. (1949). Esophageal atresia with tracheooesophageal fistula. Epidemiologic and teratologic implications. New England fournal of Medicine, 240, 987.

Panse, F., and Gierlich, J. (1949). Zur Pathogenese der Anencephalie (auf Grund der Untersuchung eines Akardius und seines Paarlings). Virchows Archiv, 316, 135.

Stevenson, A. C., Johnson, H. A., Stewart, M. I. P., and Golding, D. R. (1966). Congenital malformations. A report of a study of series of consecutive births in 24 centres. Bulletin of the World Health Organization, Vol. 34 (Suppl.).

Woolley, M. M., Chinnock, R. F., and Paul, R. H. (1961). Premature twins with esophageal atresia and tracheo-esophageal fistula. Acta Paediatrica, 50, 423.

T. J. David ${ }^{\star}$ and SARAH E. O'CaLlaghaN The General Hospital, Bristol BS1 6SY.

*Correspondence to Dr. T. J. David.

\section{Cystinuria with mental retardation and paroxysmal dyskinesia in 2 brothers}

Cystinuria is a genetically determined disease characterized by impairment of both intestinal absorption and renal tubular reabsorption of the group of amino acids cystine, arginine, lysine, and ornithine (Dent and Rose, 1951).

There is evidence of abnormal membrane transport, and both Scriver et al. (1970) and Efron (1965) reported an increased prevalence of cystinuria with mental disease. Scriver et al. (1970) suggested that homozygous cystinuria has a phenotypic effect on brain as well as upon kidney and intestine. Blasberg and Lajtha (1965) emphasized the similarity between amino acid transportation in the brain and the kidney. Criteria for the diagnosis of heterozygous and homozygous forms are considered by Harris et al. (1955), Rosenberg (1967), and Crawhall et al. (1969).

The following 2 case histories illustrate a hitherto unreported association between cystinuria and paroxysmal dyskinesia.

\section{Case reports}

Case 1. An 11-year-old boy born of unrelated parents. There was mild toxaemia during the pregnancy and delivery was by surgical induction at 38 weeks. Birthweight was $3.7 \mathrm{~kg}$. There were no neonatal problems. He smiled at 6 weeks, but thereafter his development was delayed. At 10 months of age he was found by his mother to be lying still with eyes and head deviated to the left. There was no concomitant fever or illness. A right-sided weakness resolved over the next 10 days.

During the next 4 years he had monthly episodes during which his eyes deviated to the right and he developed right-sided weakness. Sometimes these episodes were preceded by focal twitching. There was no response to phenobarbitone or primidone. On admission to hospital at 4 years it was noted that he was retarded (IQ 47, mental age 22 months), had a fluctuating strabismus, and right-sided pyramidal signs. There was no facial weakness or dysphasia.

From 4 to 11 years the nature of these episodes changed. From being periods of right-sided weakness, they became periods of tonic spasms of any or all limbs. At 8 years his right arm was held above the head in fixed flexion. Now, during these episodes which may occur several times weekly, his right arm and leg go stiff, his head extends and turns to the right, his face becomes congested, he is incontinent of urine, and though unable to speak, wails with pain. If not relieved by diazepam the attack may last all day. At other times his left arm is held in fixed flexion at the elbow and this may persist during sleep.

A recent examination revealed a retarded child with no abnormalities outside the central nervous system. His head circumference and height were within normal limits. There were no naevi or intracranial bruits. There was no inequality of limb size. He was alert with slurred speech. His left eye was rotated medially and upwards. His fundi and discs were normal. There was a left facial upper motor neurone weakness. $\mathrm{He}$ manifested generalized dystonic movements and gross ataxia bilaterally. There was variable hypertonia, muscle wasting, and a left-sided weakness more pronounced distally. His reflexes were symmetrical and normal. There was no sensory abnormality. He has had no significant previous illness.

Investigations. Aged 1 year he was found to be heterozygous cystinuric. At 4 years EEG showed focal abnormality in the left temporal area. Urine protein analysis was normal. Chromosomes were normal. At 5 years his palm prints were normal. EEG showed no focal abnormality. At 6 years serum potassium level during an episode of dyskinesia was normal. Skull $x$-ray was normal.

Aged 11 years the following tests were normal: full blood picture (no acanthocytes), cholesterol, blood amino acids, uric acid, copper, calcium, phosphorus, sugar, magnesium, liver function tests, electrolytes and urea, lead, $\alpha_{1}$ antitrypsin, IgG and IgM, 24-hour urinary VMA, ECG. EEG did not show any gross abnormality. Plasma protein electrophoresis showed a faint $\alpha_{1}$ band, IgA was raised $(165 \mathrm{IU} / \mathrm{ml})$, caeruloplasmin was $52 \cdot 4$ $\mathrm{mg} / 100 \mathrm{ml}$ (normal 20-44).

Case 2. The 12-year-old brother, born of a normal pregnancy but difficult delivery. His birthweight was $3.1 \mathrm{~kg}$. His milestones were delayed. At 2 months of age he had an episode during which his head and eyes deviated to the right and there was generalized tonic spasm. There were no obvious precipitating causes. Thereafter these episodes occurred monthly until he was 2 years old. Occasionally there was a clonic phase succeeded by a right-sided weakness for several hours. From 2 to 4 years he was free from attacks. 
Examination at 4 years revealed mental retardation but an otherwise normal central nervous system. At this time he started to have episodes involving the right side of his body during which his arm would be held flexed and immobile, he would stamp his foot, and his speech became slurred. There was no loss of consciousness. Sometimes during these episodes he would gain the use of his right hand for a few minutes, then lose it again. By 7 years these attacks were involving either the left or right side of his body and included difficulty in swallowing. They could last several days. He has had no significant previous illness.

Investigations. No biochemical abnormality was found in early life. CSF was normal. At age $1 \frac{1}{2}$ years he was found to be excreting excess dibasic amino acids. EEG showed no focal abnormality. Normal chromosomes. At 4 years IQ was 56 , mental age $2 \frac{1}{2}$ years. At 7 years the following tests were normal: full blood picture, erythrocyte sedimentation rate, blood amino acids, uric acid, calcium, phosphorus, sugar, prothrombin time, partial thromboplastin time, electrolytes and urea. In addition, a vertebral arteriogram and left carotid arteriogram were normal. EEG performed during an attack showed excess $4 / \mathrm{sec}$ activity in the posterior temporal regions, on the right side more than the left.

Family history. Mother was of dull normal intelligence, and noted to have long tapering fingers. She died aged 28 of an astrocytoma of the midbrain. She showed no abnormality of urinary amino acid excretion on one sample tested. As she was adopted, there is no medical history of her family available. The father is of dull normal intelligence. There is no other relevant family history.

\section{TABLE}

Urinary amino acids $\mathrm{mg} / \mathrm{g}$ creatinine

\begin{tabular}{|c|c|c|c|c|}
\hline & Cystine & Lysine & Ornithine & Arginine \\
\hline $\begin{array}{l}\text { Father } \\
\text { Case } 2 \\
\quad \text { (aged } 7 \text { yr) } \\
\text { Case } 1 \\
\quad \text { (aged } 6 \text { yr) }\end{array}$ & $\begin{array}{l}122 \\
785 \\
844\end{array}$ & $\begin{array}{r}162 \\
1086 \\
1233\end{array}$ & $\begin{array}{r}19 \\
120 \\
132\end{array}$ & $\begin{array}{r}8 \\
43 \\
32\end{array}$ \\
\hline
\end{tabular}

\section{Discussion}

Both brothers excreted amounts of cystine, lysine, and ornithine in the upper range of incompletely recessive heterozygote cystinurics. The amounts of arginine excreted were, however, much lower than those usually associated with cystinuria. The urine levels of cystine and lysine were also slightly raised in the father. Data about such ranges have been given by Crawhall et al. (1969) and Patton (1967).

There are reports in published cases of dystonic posturing occurring as an episodic spasmodic disorder without loss of consciousness. Generally there is a characteristic precipitating factor. Thus, in the cases described by Stevens (1966), Lishman et al. (1962), and Whitty, Lishman, and FitzGibbon (1964) sudden movement was the cause, whereas it was emotion in Levin's case (1934). But none of these cases had a reported association with aminoaciduria.

On the other hand cystinuria has been described in association with a variety of neurological conditions: with mental retardation (Berry, 1959; Visakorpi and Hyrske, 1960), with muscular dystrophy (Hurwitz et al., 1967), with muscular hypotonia (Clara and Lowenthal, 1966), and with paraplegia (Banerji and Millar, 1971).

It appears to us that these 2 brothers either represent the independent coexistence of two rare conditions, both genetically determined, or else the conditions are dependently related. We feel that statistically the latter alternative is more probable.

\section{Summary}

Two brothers presented before the age of 1 year with a history of delayed development and onset of focal epileptic attacks. They were discovered to be excreting amounts of cystine, lysine, and ornithine in the upper range of incompletely recessive heterozygote cystinurics. Around the age of 4 years they began to have episodes of paroxysmal dyskinesia. It seems likely that the neurological condition, which in both boys is slowly progressive, is related to their biochemical abnormality.

We thank Dr. John Wilson for his permission to report details of his cases and for his helpful criticisms and suggestions.

\section{REFBRENCES}

Banerii, N. K., and Millar, J. H. D. (1971). Paraplegia associated with cystinuria. Fournal of the Neurological Sciences, 12, 101.

Berry, H. K. (1959). Cystinuria in mentally retarded siblings associated with atypical osteogenesis imperfecta. American Fournal of Diseases of Children, 97, 196.

Blasberg, R., and Lajtha, A. (1965). Substrate specificity of steady-state amino acid transport in mouse brain slices. Archives of Biochemistry and Biophysics, 112, 361.

Clara, R., and Lowenthal, A. (1966). Familial and congenital lysine-cystinuria with benign myopathy and dwarfism. Fournal of the Neurological Sciences, 3, 433.

Crawhall, J. C., Purkiss, P., Watts, R. W. E., and Young, E. P. (1969). The excretion of amino acids by cystinuric patients and their relatives. Annals of Human Genetics, 33, 149.

Dent, C. E., and Rose, G. A. (1951). Amino acid metabolism in cystinuria. Quarterly fournal of Medicine, 20, 205.

Efron, M. L. (1965). Aminoaciduria. New England fournal of Medicine, 272, 1058.

Harris, H., Mittwoch, U., Robson, E. B., and Warren, F. L. (1955). Phenotypes and genotypes in cystinuria. Annals of Human Genetics, 20, 57.

Hurwitz, L. F., Carson, N. A. J., Allen, I. V., Fannin, T. F., Lyttle, J. A., and Neill, D. W. (1967). Clinical, biochemical and histopathological findings in a family with muscular dystrophy. Brain, 80, 799. 
Levin, M. (1934). Paroxysmal hypertonia induced by affect; symptom in man and in lower animals. Archives of Neurology and Psychiatry, 32, 1286.

Lishman, W. A., Symonds, C. P., Whitty, C. W. M., and Willison, R. G. (1962). Seizures induced by movement. Brain, 85, 93.

Patton, V. M. (1967). Ph.D. Thesis. University of Oxford.

Rosenberg, L. E. (1967). Amino Acid Metabolism and Genetic Variation, p. 341 . Ed. by W. L. Nyhan. McGraw-Hill, New York.

Scriver, C. R., Whelan, D. T., Clow, C. L., and Dallaire, L. (1970). Cystinuria: increased prevalence in patients with mental disease. New England fournal of Medicine, 283, 783.

Stevens, H. (1966). Paroxysmal choreo-athetosis. A form of reflex epilepsy. Archives of Neurology, 14, 415.

Visakorpi, J. K., and Hyrske, I. (1960). Urinary amino acids in mentally retarded patients. Annales Paediatriae Fenniae, 6, 112.

Whitty, C. W. M., Lishman, W. A., and FitzGibbon, J., P. (1964). Seizures induced by movement: a form of reflex epilepsy. Lancet, 1, 1403.

N. P. C. Cavanagh, ${ }^{\star}$ J. Bicknell, and F. Howard The Hospital for Sick Children, Great Ormond Street, London; Botleys Park Hospital, Chertsey; and Middlesex Hospital, London.

*Correspondence to Dr. N. P. C. Cavanagh, Department of Neurology, Guy's Hospital, London SE1 9RT.

\section{Treatment of phenothiazine drug intoxication with benztropine}

A Parkinsonian syndrome, dystonia, dyskinesia, and akathisia are well known toxic effects of the phenothiazine drugs, particularly the piperazine derivatives which include perphenazine, fluphenazine, prochlorperazine, and thiopropazate. Dyskinetic states appear early and may be severe, suggesting a diagnosis of tetanus (Ramsden and Froggatt, 1972; Snowdon, 1972). 2 cases of such reactions are reported, 1 presenting with a pseudotetanic state and the other with a generalized epileptiform convulsion.

\section{Case reports}

Case 1. A 10-year-old girl was admitted in October 1972 with a history of having had 2 separate episodes of arching her back, rolling her eyes, and protruding her tongue, accompanied by rigidity of her arms and legs. Each episode lasted only a few minutes and had started about 4 hours previously. On further questioning she had started vomiting 3 days before and had been put on perphenazine $3 \mathrm{mg}$ three times a day by her general practitioner.

On examination she was quite alert and orientated; her neck was extremely stiff but Kernig's sign was negative. Her eyes deviated upwards intermittently but there was no nystagmus, photophobia, or papilloedema. The upper limbs appeared normal, though in the lower limbs the tone was increased and the reflexes very brisk.
Investigations included a lumbar puncture which yielded normal CSF (1 leucocyte and $9 \mathrm{red}$ cells $/ \mathrm{mm}^{3}$ and protein $7 \mathrm{mg} / 100 \mathrm{ml}$ ). White blood count was $5000 / \mathrm{mm}^{3}$ with a normal differential and the ESR was $7 \mathrm{~mm} / \mathrm{hr}$.

After admission she started having almost continuous oculogyric crises associated with opisthotonus and spasms of her facial muscles with difficulty in swallowing. Her clinical state was highly suggestive of tetanus but there was no history of a recent wound and her tetanus toxoid innoculations were up to date.

In view of the recent perphenazine administration she was given benztropine $0.5 \mathrm{mg}$ intravenously. After 1 minute her ocular movements became less severe and in 10 minutes the facial spasm resolved and the swallowing became easier. Half an hour later she was given another $0.5 \mathrm{mg}$ benztropine intravenously and within 5 minutes her back straightened and she was able to flex her neck. Over the next few hours she remained hyperexcitable but had no further spasms and was discharged the following day.

Case 2. In March 1973 a 7-month-old boy was admitted having been given five $3 \mathrm{mg}$ doses of perphenazine syrup. This had been prescribed as a tranquillizer for his mother who had confused it with a similar-looking cough medicine given to the child. Apart from being miserable and sleepy on the day of admission he had no symptoms. On examination he was drowsy and irritable and had increased tone in his upper and lower limbs. There was no neck stiffness. He was admitted for observation.

Six hours later he developed marked rigidity of his limbs accompanied by jerky, dyskinetic movements of his arms and spasms of his facial muscles. The arms were held stiffly up in the air and if pressed down to his sides and then released, immediately returned slowly to their original position. The dystonia and dyskinesia steadily increased in severity until he appeared to be having a grand mal convulsion. Remembering our experience of 6 months before, we gave him benztropine $0.25 \mathrm{mg}$ intravenously; within 1 minute the increased tone diminished, the dyskinetic movements ceased, and a look of relief came over the child's face. There were no further symptoms and he was discharged the next day.

\section{Discussion}

These 2 cases show severe forms of the dyskinetic reactions to a phenothiazine drug. Gupta and Lovejoy (1967) reviewed 20 similar patients under 15 years of age and found the commonest symptoms to be drowsiness, cogwheel rigidity, opisthotonus, and hyper-reflexia, and 2 patients had trismus with convulsions and oculogyric crises. The time of onset was up to 50 hours after the original dose, but in 6 out of 7 cases of accidental ingestion it was within 5 hours. The erroneous diagnosis of tetanus is easily made on the physical signs and referral to an infectious disease unit is not unknown (Mandal and Sengupta, 1972). Diagnoses of encephalitis and, in 